\title{
Specifics of Musical Thematism, Harmonious Language, Polyphonic Technique and form in the Secular Choral Music of Dobri Hristov
}

\author{
Zdravka Hvarkata \\ Department of Music, Faculty of Pedagogy, Plovdiv University of Paisii Hilendarski, Plovdiv, Bulgaria
}

Email address:

hvarkata@mail.bg

To cite this article:

Zdravka Hvarkata. Specifics of Musical Thematism, Harmonious Language, Polyphonic Technique and form in the Secular Music of Dobri Hristov. International Journal of Literature and Arts. Special Issue: Musical Theory, Psychology, Pedagogy and Performing. Vol. 3, No. 5-1, 2015, pp. 55-61. doi: 10.11648/j.ijla.s.2015030501.18

\begin{abstract}
The two types of themes in the secular choral music of Dobri Hristov - with a folklore character and in common tone, determine the specifics of the approach of the composer in the major compositions developed on their basis. Comparing the specific features of the harmonious language, the polyphonic methods and the structural solutions in the two types of works, we acquire a good idea of the complete image of this major part of the musical heritage of the composer.
\end{abstract}

Keywords: Secular Choir Music, Themes with a Folklore Character, Themes in a Common Tone, Specifics of the Harmonious Language, Types of Polyphonic Technique, Specifics of the Form

\section{Introduction}

Dobri Hristov was a key figure among the Bulgarian composers who started their creative careers immediately after the Liberation of Bulgaria from Ottoman rule in 1878, and secular choir music constitutes a considerable part of his cultural heritage. The specifics of its thematism, the peculiarities of the development of his polyphonic retionalization, both vertical and horizontal, as well as the logic of his development of the form, are to a large extent indicative of the artistic signature of the composer. That is why the general conclusions we can draw on the basis of personal analyses and the observations of other researchers, bear no relation to the secular choir music of Dobri Hristov only.

\section{Subject, Objectives and Targets of the Research}

The subject of the research is the nature of the themes due to their significance of basic building components of the musical work and the way, determined by the themes, in which the process of developing the form is realized. The objectives of this study are: to summarize the peculiarities of the harmonious rationalization, polyphonic techniques and structural development of the secular choir works of Dobri Hristov, depending on the type of themes underlying the: with a folklore character and in a common tone. The aims we have set include studying the specific characteristics of the two types of works.

\section{Specific Features of Musical Works Created on the Basis of Themes of a Folklore Type}

The folklore type of themes, including authentic, 'over-written' folk songs, and entirely author songs, is of a particular interest, as the most popular choir works of the composer, favourite of several generations of Bulgarians. According to the sound and accurate judgment of Iskra Racheva, 'the recreation of the folk song tradition in the works of D. Hristov...marks the highest achievements in the approach of a whole generation of composers to the folk song - of this specific approach constituting the first stage of synthesizing the folk-song intonation basis and the Western European tone systems..." (,претворяването на народнопесенната традиция в творчеството на Д. Христов ... бележи най-високите достижения в подхода на цяло едно поколение композитори към народната песен на този характерен подход, който представлява първата 
степен на синтезиране на народнопесенната интонационна основа и западноевропейската тонова система...") [6, с. 3].

An important prerequisite for this synthesis is the focus on a relatively more modern, chronologically closer folklore layer in which the modal organization of the folk song reach as closely as possible the tonal type of major-minor thinking. Very revealing in this respect is the fact that it is only in the last song of the 'Three Christmas songs' cycle (цикъла „Три коледни песни“) that the theme used is close to the archaic Christmas melodies, so typical of the Bulgarian folklore. However, it is no accident that its polyphonic scheme is one of the reasons for this musical work's not being among the most repertory works of the composer.

Of course, there are some highly artistic songs in Dobri Hristov's works with themes going back further back in time, such as the rebels' song 'The forest swayed' („Вила се й гора“) whose miniature nature is inversely proportionate to its artistic impact:

Example 1: 'The forest swayed' („Вила се й гора“)
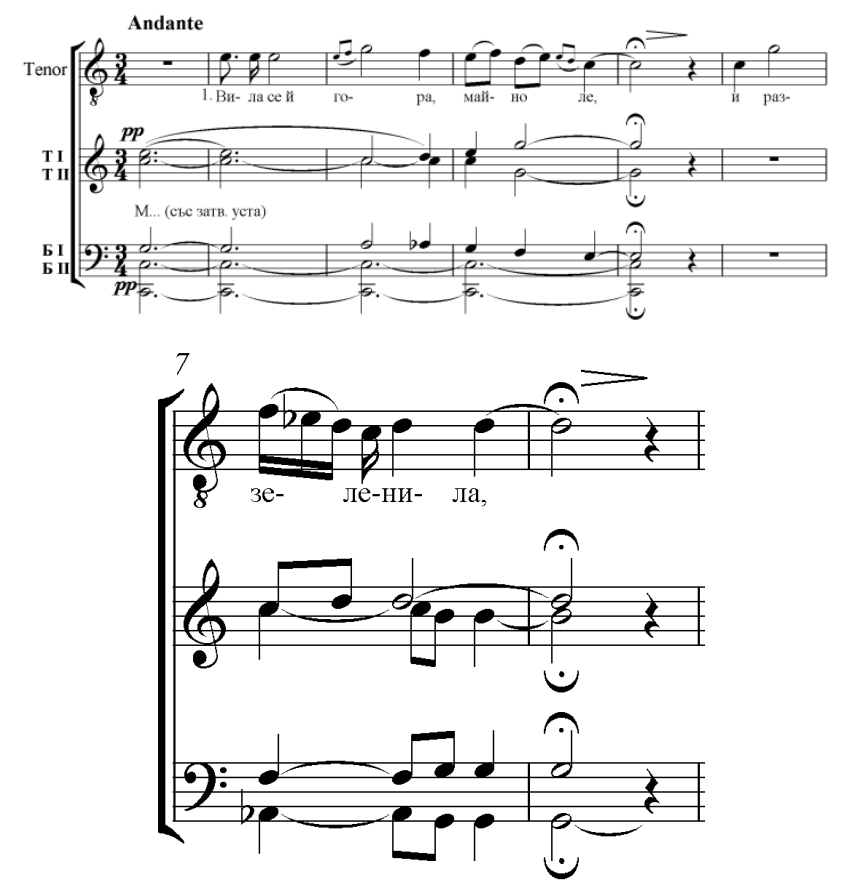

From a wider musical-historic perspective, this trend towards the temporally closest folklore layers is a major one in the works of the first Bulgarian composers, easily explained by the fact that they constituted a part of their actual sound environment. Lyuben Botusharov remarked in one of his studies dedicated entirely to the issues of the Bulgarian professional music in the first decades after the Liberation: "... it was in those later intonation layers of our folk music that the first Bulgarian composers were engrossed in their everyday life.” („,... в тия по-късни интонационни пластове на народната ни музика са били потопени в своето всекидневие първите български композитори“) [1, с. 64]. The conclusions made by Neva Krasteva in her research into the individual polyphonic styles in the Bulgarian musical culture, are also in this line of thought: ,... the emphasis in the choice of folklore material is on the monody with a wide range, mostly in the varieties of major and minor, most of a relatively later origin and of an urban type" (,,.. акцентът при избора на фолклорен материал пада на монодията и особено на развитите, богати мелодии с широк диапазон, най-често в разновидностите на мажора и минора, повечето със сравнително късен произход и от градски тип“) [5, с. 70].

Important observations on the specifics of the thematic vertical in the works of Dobri Hristov and his contemporaries, predetermined by the folklore type of themes, are stated in the article by Mariana Buleva "Embodiments of the major-minor tonal system in Bulgarian music as a historical-theoretic issue' („Превъплъщенията на мажоро-минорната тонална система в българската музика като историко-теоретичен проблем“"): 'Employing classical harmony in their compositions as a means of harmonization of the already existing melody (born in the modal monophonic vocal practice in accordance with entirely different principles of melody development), the first Bulgarian composers create a truly 'non-classical state of tonality' in the most literal sense of this expression..." „Turning the prevailing melodies (or the author melodious inventions created in this vein) in an object of composers' recreation, .......our first tone-masters deprive classical harmony of its own classical meaning" („Привличайки класическата хармония в своите композиции като средство за хармонизация на вече съществуваща мелодия (родена в модалната едногласна вокална практика от съвършено други закони на мелоразгръщане), първите български композитори формират едно действително „,некласическо състояние на тоналността“" в най-прекия смисъл на този израз ...“; „Превръщайки битуващите мелодии (или сътворените в техен дух авторски мелодични открития) в обект на композиторско претворяване, ... пьрвите ни тономайстори отнемат на класическата хармония собствено класическия ѝ смисъл“") [2, с. 122-123].

Iskra Racheva comments on the common end of the dominant, which acquires a new functional meaning and is auditorily perceived as tonic: "The reasons for this are in the exceptional modal and intonation stability of the final melodic cadence in the folk song, of the final tone in the role of the tonic. In harmony with the dominant, it retains its tonic meaning, i.e. it remains a tonic of some sort, which 'overlays' the dominant harmony, changing radically the notional and structural meaning of the dominant to become the focus of the modal and tone propensities and the most powerful source of modal dynamics” (,Причините за това са в изключителната ладова и интонационна устойчивост на заключителната мелодическа каденца в народната песен, на заключителния тон в ролята на тоника. Хармонизиран с доминанта, той запазва тоническия си смисъл, т.е. остава си своего рода мелодическа тоника, която се „наслагва“ на доминантовата хармония, изменяйки из основи смисловото и конструктивното значение на доминантата да бъде фокус на ладотоналните тежнения и най-мощен източник на ладов динамизъм“) [6, с. 9]. Vivid examples of this type of ending in the secular choral music of Dobri 
Hristov are songs, such as 'It has started swaying' („Айде завила се“), 'It caught fire, Treno, sweetheart' („Се запали, пиле Трено“), 'Oh, lass’ („Ой, девойче, войче“), etc.

Example 2: 'Oh, lass, lassie’ („Ой, девойче, войче“)

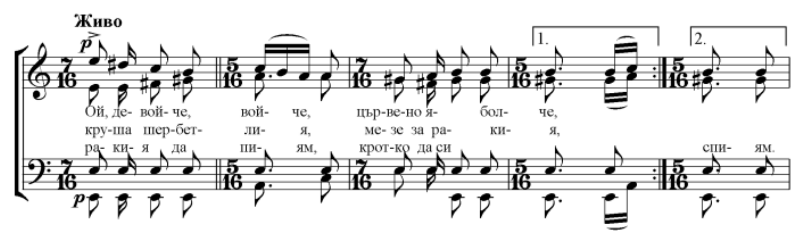

The quoted conclusions of the researchers provide an answer to the question why, in the most valuable secular choral works of Dobri Hristov, the harmonizations with the aid of classical functionality, subjected to a lot of criticism, do not sound unconvincing, as it would be logical to expect; they explain various aspects of this seeming paradox. The modern Bulgarian musician may regard Dobri Hristov's harmonic solutions as naïve and not particularly skillful at times (especially in comparison with those of Filip Kutev, Lyubomir Pipkov or Dimitar Nenov, as well as later composers such as Krasimir Kyurkchiyski, Ivan Spasov, etc.). In the best examples, however, the vertical interpretation of the folklore type of themes is no less convincing and impressive with the specifics of the approach than in the works of the masters referred to above - the harmonious language of the composers who worked in different historical periods, are part of their original author's style and are a vivid evidence of the spirit of the time in which they worked.

The question of the polyphonic treatment of the folklore type of themes in the secular choral music of Dobri Hristov includes its horizontal development. In the quoted study of Neva Krasteva, a general peculiarity is pointed out with regard to the first Bulgarian composers: 'The folklore types of polyphony are represented due to the naturally chosen thematic material in a form far from the folklore prototype, subjected to harmony norms corresponding to this type of melodic' („Народните типове многогласие са представени поради естествено избрания тематичен материал във вид далечен от фолклорния прототип, подчинени на хармоничните норми, отговарящи на този тип мелодика“) $[5$, p. 70]. This conclusion is totally applicable to the part of Dobri Hristov's works we are interested in, as it is clear from the examples given by the author. Among them are the bourdon stylization in the alto part of 'Frost has fallen, Gane' („Слана падна, Гане“), the parallel second movement in the coda of 'Bachelor grandpa' („Ерген дядо“) (though marked as an exception), the antiphone refrains of different length and in a different tone in the same song, the episode of 43-53 time in 'Damn lasses from Zharavna' („Пусти моми жеравненки“), in which 'the idea of the endless canon serves as an ornamental-canonic development of the material' (,идеята за безкрайния канон служи за орнаментално-каноническата разработка на материала“) [5, p. 77], the contrasting polyphony, once again, in 'Bachelor grandpa' („Ерген дядо“) (from time 25), creating from time 41 even 'an impression of a search for a counterpoint' („впечатление за тьрсене на четворен контрапункт") [5, p. 75], the combination of antiphone, an endless canon of the first type (according to Taneev's classification) and the canonic sequence using an octave turn-point counterpoint in 'Rachenitsa' („Ръченица“) ...

Example 3: 'Rachenitsa' („Ръченица“) - endless canon of the first type

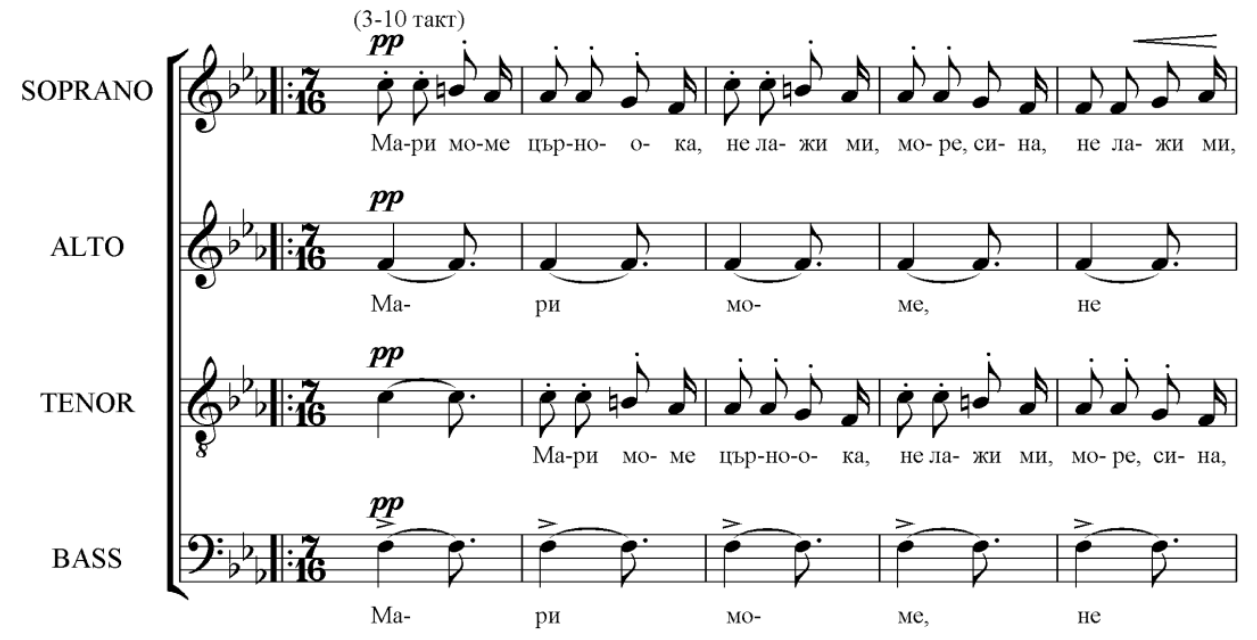




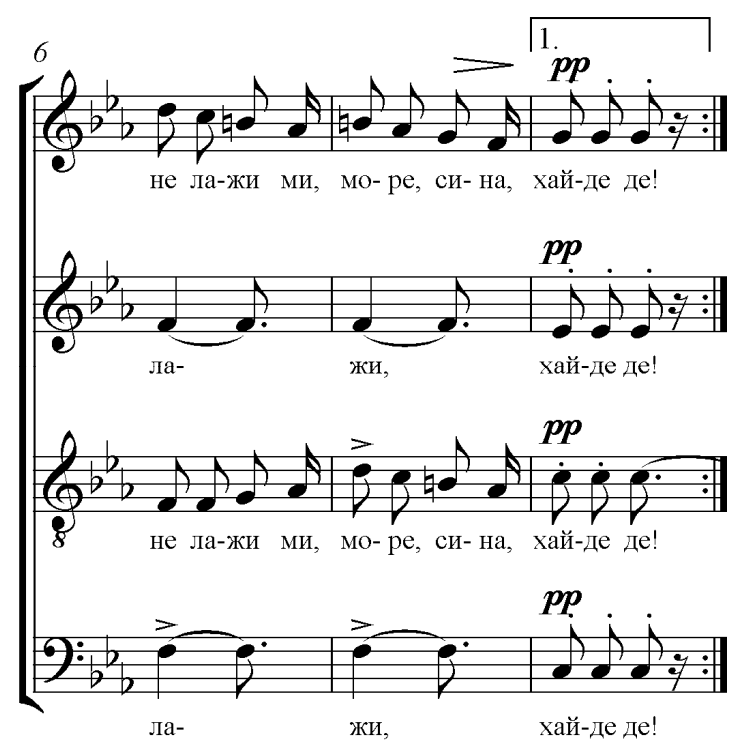

The list is far from complete - other examples are also provided, but even so the picture of the polyphonic techniques used by Dobri Hristov in developing folklore-type themes is vivid enough.

The specifics of the folk song, used as a theme in the only fugue in the works of the composer, is of particular interest. Among the factors facilitating the creation of the fugue are the initial interval of ascending quint, inspiring anticipation of a tonal response, and the diatonic structure allowing for a smooth transposition in minor. The atypical but laden with sophistication specific features of the theme include the irregular methrum and its length.

Example 4: 'Slender Dafino' („Тенка Дафино“)

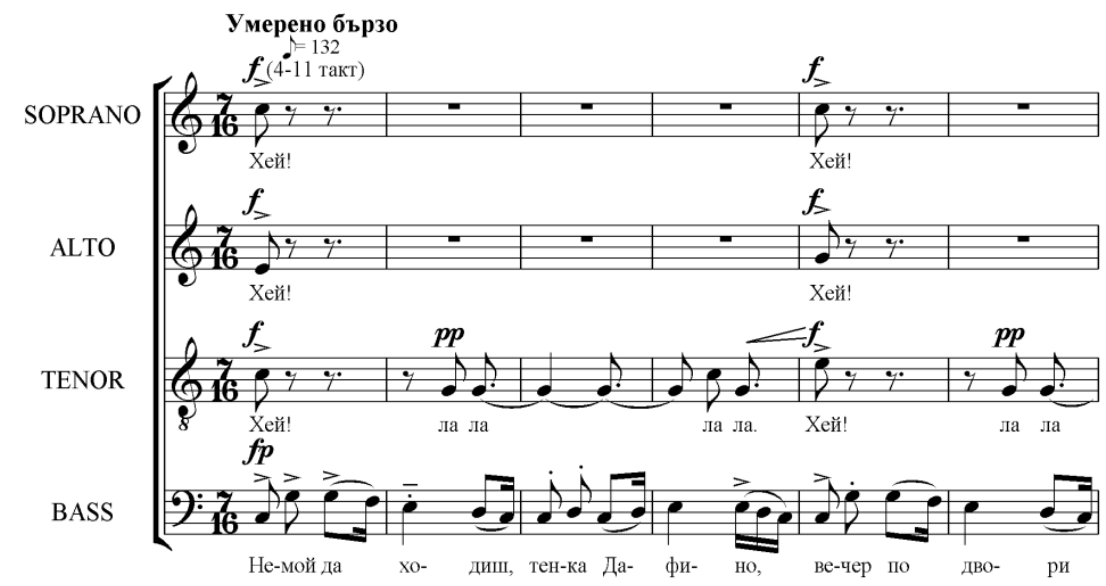

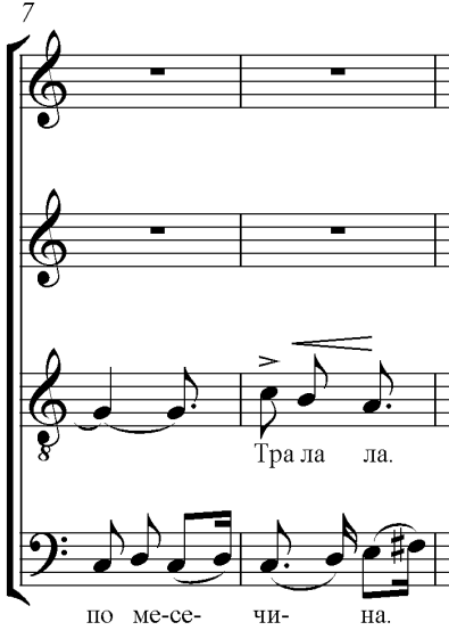

We can draw the conclusion that the folklore source - the main building material of the choral fugue 'Slender Dafino' („Тенка Дафино“) - was chosen by Dobri Hristov very carefully, taking into account the series of important factors and requirements to the fugue, which allowed him to use a variety of polyphonic techniques, which bring the work closer to the fugue-ricercare.

The organization of the form in structural terms and from the point of view of its process development is also an important problem connected with the development of the folklore type of themes in the secular choral music of Dobri Hristov.

The established in the works of his older colleagues choral potpourri reaches a peak in the compositions of Dobri Hristov. A series of deficiencies, typical of the genre, are overcome to a large extent in 'Beautiful Lilyana' (,Лиляна мома хубава“) 
and 'Damn lases from Zheravna' („Пусти моми жеравненки“), and the compilative nature of the genre is less markedly expressed thanks to the overall line of songs, strung like beads one after the other, and the generalizing function of the last song. The problem of the organization of the material is solved in the simplest possible way through a mechanical alternation of authentic folk melodies, contrasting in character.

The question of the development of the musical entity in the choral songs of the composer is a different matter. Despite all the individual features of each work, several groups can be differentiated with curious common regularities.

In the cases in which Dobri Hristov simply harmonizes, 'arranging' („нарежда“) in his own specific expression authentic folk songs, the problem of the form is solved a priori, as their structure coincides with that of the folklore source. We come across a series of such examples in the collection of 'Macedonian songs' („Македонски песни“) - 'It started swaying' („Айде завила се“), 'Oh, lass' („Ой, девойко“), ‘Oh, lass, lassie’ („Ой, девойче, войче“), 'Lass, dove'(„Девойчиня гугутчиня“), 'Lass, slender and tall' („Девойче танко, високо“), etc. Some of them do not exceed a period, while others are developed as a simple two-partition form of a developing type - 'Oh, lass, lassie' („Ой, девойче, войче“), 'It started swaying' („Айде завила се“), 'Saa nok' („Саа нокь“), etc. Apparently, this kind of musical thinking is typical of the folk singer when he creates longer melodies. That is why the fact that when citing short authentic folk songs and developing them in bigger forms, Dobri Hristov, as an expert in the specifics of the Bulgarian folklore, resorts to such kind of development, is far from surprising 'It caught fire, Treno, sweetheart' - „Се запали, пиле Трено“).

In this way, his transition to the other group of songs - those with a greater number of measures - is smooth and natural. According to Ivan Hlebarov, who expressed his ideas in his study of Bulgarian musical culture from the Liberation to 1944 'in the choral songs of D. Hristov, on the basis of folk themes a kind of multi-partition complete structure is formed. In it, the initial impetus of the folk song gives rise to a relatively developed open song form in which the song beginnings are preserved due to the symmetrical movement of alternating periods, yet at the same time, individual composer's works of scale come to life. This multi-partition feature can be differentiated from the two- partition one in 'It caught fire, Treno, sweetheart', (a, b), through the three-partition one in 'Frost has fallen, Gane' $(a, b, c)$ to the four-partition 'Rachenitsa' (a, b, c, d)' (,в хоровите песни на Д. Христов върху народни мотиви се формира своеобразна проста многоделна безрепризна структура. В нея първоначалният „тласък“ от народната песен поражда относително развита отворена песенна форма, при която песенното начало се запазва поради симетричното движение на редуващи се периоди, но същевременно възниква мащабността на индивидуално композиторско творчество. А тази многоделност може да бъде най-различна: от двуделната „Се запали, пиле Трено“ (a, b) през триделната „Слана падна, Гане“ (a, b, с ...) до четириделната „Ръченица““ (a, b, c, d).“) [7, p. 145].

It has to be admitted that concerning the form of some of the works cited by Hlebarov there are other, no less justified views: for example, in compliance with the doctrine-established systematization in musical analysis, Pencho Stoyanov, in his chrestomathy of analyses of Bulgarian music of 1966, discusses 'Rachenitsa' („Ръченица“) as a specifically developed sophisticated two-partition form - a combination of complete simple three-partition and a simple two-partition form of a developing type. A similar development within the complicated two-partition form, however, is utterly atypical of the Western European musical tradition; therefore, the theoretical justification of a new type of structural solution, such as the one proposed by Ivan Hlebarov, is quite logical.

In the simple form, comprising a variable number of partitions, despite the lack of reprise, there are intonation links between the partitions, which contributes to their internal unity. That is why the conclusion of Pencho Stoyanov concerning 'Rachenitsa' („Ръченица“) can be referred to the other choral songs of Dobri Hristov with a similar structure 'the problem of the largescale form in the Bulgarian choral literature is put on the agenda and solved' (,поставя и успешно решава проблемът за крупната и широкомащабна форма в българската хорова литература““) [3, p. 33].

Needless to say, among the choral songs of Dobri Hristov with folklore themes there are also compositions of a more conventional development type. According to Ivan Hlebarov, the song 'Oh, lass' („Леле моме“) is a sort of a 'compromise with the non-traditional open multi-partition form' (this conclusion is illustrated with an expose of the scheme of a complex three-partition reprise form with the following structure: A /aba/ B / $\left.b_{1}, b_{2} / A_{1} / a b /\right) ~[7, p .145]$. The variations in 'Petru Petruvlyanku' („Петру Петрувлянку“) are also unique - there are variations only in the first period of the theme developed as a simple two-partition form, the second is repeated without any variation; the motorics of the toccata-type of movement in 'Bachelor grandpa' (,Ерген дядо“) makes it more difficult to distinguish between the partitions, and allows for various interpretations. And so on undoubtedly, there are many more examples in which the form of the choral song can be successfully interpreted as one of the established structures, systematized in musical analysis, but almost always the way in which this structure is realized is really specific and unique. And this specifics, as it has already become clear, is predetermined by the characteristics of the folklore-type of themes underlying them, giving rise to a series of regularities in the development.

In the form of the three patriotic hymns of Dobri Hristov 'Pirin Mountain' („Пирин планина“), 'A single cry is heard' („Едничък чуй се вик“), and 'Eulogy for Macedonia' („Възпев на Македония“) - there are no deviations as compared to the regularities typical of Western European music: the simple two-partition form (with reprise or of a developing type) is characterized by clear articulation and the usual logic of development. The reason for this phenomenon is to be found again in the character of the themes used, with a 
strong influence of the urban song connected with the Western European musical thinking.

The themes underlyng the ballad 'Dobrinka and the sun' („Добринка и сльнцето“) can also be defined as folk, though conditionally: in his monograph on Dobri Hristov, Ivan Kamburov correctly points out that 'to this highly poetic ballad, the composer adds music in measures typical of folk music, yet the purely musical development is not based on musical folklore, which is felt at times in its overall feel' (,на тази високопоетична народна балада народният композитор написва музика в присъщите на народната музика тактове, но чисто мелодическото градиво не е заимствувано от музикалния фолклор, а само тук-таме се усеща нещо от неговия дух“) [4, p. 112]. In spite of the numerous parts constituting the form, it possesses a kind of internal balance achieved thanks to the flexible alteration of epic and lyrical themes (in this work, epic and lyrical themes are juxtaposed, with the discussed indirect link with folklore being present in both types).

The structure of the fugue 'Slender Dafino' is to a large extent predetermined by the strict regularities which the development of this highly imitation-polyphonic form subjected to. Yet, the way in which the rhythm-intonation potential of the theme is used and the process development is realized, there are some typical features - modulating to dominant tonality codetta, with which the first exposition of the fugue theme finishes, the sequence of the initial appearance of the voices, from the lowest to the highest one, the multitude of polyphonic ideas. The careful choice of themes - the suitable for imitation-polyphonic development Macedonian folk song 'Slender Dafino' - gave the composer the opportunity to solve in an exceptionally successful way the difficult task of coping convincingly with the form of the first fugue in Bulgarian professional music.

\section{Specific Features of Compositions Created on the Basis of Themes in a Common Tone}

The concert choral songs of Dobri Hristov are mostly compositions based on themes of folklore nature - we can point out a quite limited number of examples of songs in common tone among them: the first one of the cycle 'Three Christmas songs' („Три коледни песни“) - 'Wake up, lass' („Стани, стани, момне ле“), the final partitions of 'Don't raise your voice, lass' („Не извишай, моме, гласи“), and the composition, larger in scale, 'He is alive' („Жив е той“").

„Wake up, lass“ („Стани, стани, момне ле“) written in 7/16 -methrum and in the rhythm of the rachenitsa, despite its methrorhythmic organization, however, it, according to the justified remark in Venelin Krastev's monograph on the composer, has no folklore character and is actually closer to Dobri Hristov's songs in a common tone for children.

Example 5: „Wake up, lass“ („Стани, стани, момне ле“)
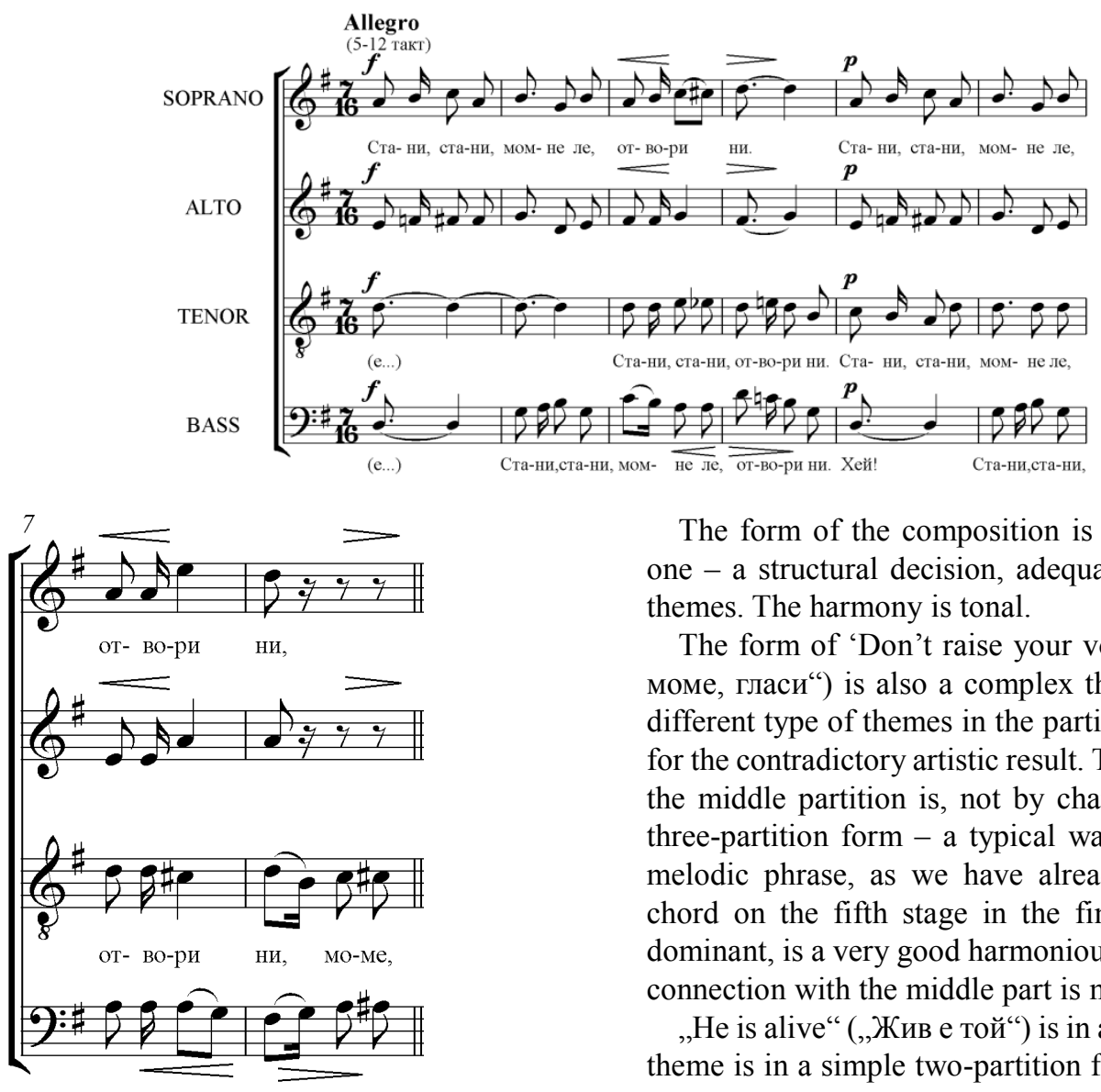

The form of the composition is a complex three-partition one - a structural decision, adequate to the character of the themes. The harmony is tonal.

The form of 'Don't raise your voice, lass' („Не извишай, моме, гласи“) is also a complex three-partition one, but the different type of themes in the partitions is one of the reasons for the contradictory artistic result. The moderate rachenitsa in the middle partition is, not by chance, a non-reprise simple three-partition form - a typical way to develop the folklore melodic phrase, as we have already explained. The minor chord on the fifth stage in the final parts, substituting the dominant, is a very good harmonious idea, and thanks to it the connection with the middle part is more natural.

„He is alive“ („Жив е той“) is in a form of variations whose theme is in a simple two-partition form of a developing type. 
The active use of plagal harmonies and mediants is an important part of the overall epic-eulogy sound of the composition, and the imitation polyphonic technique used in the second variation is combined with an interpretation of the vertical - an approach contributing to the multi-dimensional development of the theme.

A great part of the military and school songs of Dobri Hristov are in common tone - they continue the tradition established in the Revival songs of the middle of the $19^{\text {th }}$ century. The most-sung of the military songs of the composer - 'Towards heroic deeds and glory!'(„Напред към подвизи и слава!“) , and 'We are coming, enemy' („Идем, идем, сган проклета") - the themes are exactly of that type. The marches are in a simple two-partition form of a developing type, with the first partition being the stanza, and the second - the refrain of the song. The melodies are harmonized with a classical type of functionality, and the polyphonic structure (quadraphonic in the first, and triphonic in the second march) is in placed reduced to unison whose powerful mobilizing effect cannot logically be excluded from the arsenal of means of expression in view of the specifics of the genre.

\section{Conclusions}

The two types of themes in the secular choral music of Dobri Hristov - with a folklore character and in common tone, determine the specifics of the approach of the composer in the compositions developed on their basis. Comparing the specific features of the harmonious language, the polyphonic methods and the structural solutions in the two types of works, we acquire a good idea of the complete image of this major part of the musical heritage of the composer.

\section{References}

[1] Botusharov, L., From the rachenitsa to the laendler and backBulgarian Musicology, 1997, No.3

[2] Buleva, M., Transformations of the major-minor tonal system in Bulgarian music as a historical-theoretical problem. $\mathrm{N}$ : Bulgarian historical musicology. Approaches and concrete examples. M: SBK, Section 'Musicologists', 2005

[3] Bulgarian music. Chrestomathy with analyses. M: Public education, 1966

[4] Kamburov, I., Dobri Hristov. Life and work of the popular composer., M.: Ignatov, 1942

[5] Krasteva, N., Musical theoretical research. Vol.1, M: SP Leading Technology, 2002

[6] Racheva, I., Dobri Hristov from the perspective of the modal thinking in Bulgarian folk and professional music. - Musical horizons. 1989, № 11

[7] Hlebarov, I., The new Bulgarian musical culture. Volume one: 1878 - 1944, M.: Heini,, 2003 